\section{Kopsine and Strychnine: a Comparative Study of their Physiological Properties}

Kopsine, an indoline alkaloid, has been isolated from the leaves of Kopsia albiflora, L. and Kopsia fructosa, A.Dc. (Apocyanaceae) ${ }^{1,2}$. It is a monoacidic base, and its chemical structure has been found ${ }^{3}$ to be as shown in Fig. 1.

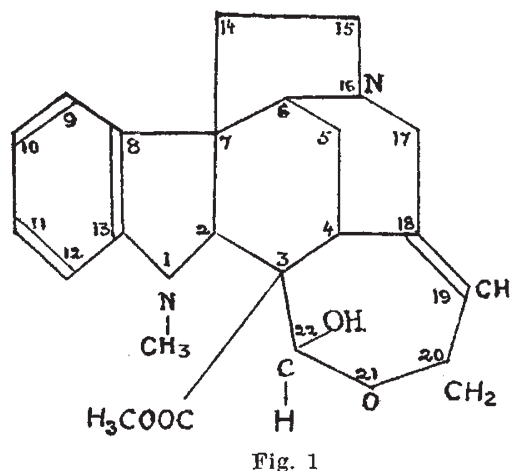

Structurally, it has some similarity to some of the strychnos $^{4}$ and picralima 5,6 alkaloids. It has been suggested ${ }^{3}$ that the structural configuration at carbon atom 3 (that is, the allocation of $-\mathrm{COOCH}_{3}$ and cyclic acetal) fits into the modern conception of biogenesis of strychnos alkaloids?

The physiological properties of kopsine have been studied and the results have been compared to those of strychnine under identical conditions. The $p \mathbf{H}$ of the solutions of strychnine and kopsine was $6 \cdot 5$. A control study was made in each case by using Ringer's solution with $p \mathbf{H}$ adjusted to $6 \cdot 5$.

(1) Strychnine (1 mgm.) increases the excitability of the motor nerve cells. This action is very marked when strychnine is applied directly to the spinal cord. The same dose, or even higher doses, of kopsine show little effect. Preparations of spinal cord, nerve and muscles in toads were used for this work.

(2) Directly applied to the smooth muscles of the intestine or uterus of virgin rats and guinea pigs, $3 \mathrm{mgm}$. of strychnine has no effect. Kopsine in the same dose (3 mgm.) increases both the rate and amplitude of contraction of such muscles.

(3) Strychnine at a dose of $0 \cdot 2-0 \cdot 3 \mathrm{mgm}$. does not affect the cardiac contraction of toads. Kopsine at a dose of $0.2 \mathrm{mgm}$. reduces the cardiac con. traction-both rate and amplitude. This effect becomes more pronounced as the dosage of kopsine is increased. With high dosage $(0.5 \mathrm{mgm}$.$) , there$ is temporary cessation of the cardiac activity. For such investigations, toad heart perfusion experiments have been used.

(4) Neither strychnine nor kopsine influences the peripheral blood flow in toads as studied by the flow pressure perfusion technique at is dose of $100 \mathrm{mgm}$. per $100 \mathrm{ml}$. and by venous drop recording method using $5-15 \mathrm{mgm}$. of either.

(5) In urethane-anæsthetized cats, strychnine in the dose $2 \mathrm{mgm}$. per $\mathrm{kgm}$. body-weight lowers the blood pressure slightly only (8-12 per cent) when the basal level of blood pressure is between 120 and $140 \mathrm{~mm}$. mercury. Kopsine at a dose of $2 \mathrm{mgm}$. per $\mathrm{kgm}$. body-weight reduces the blood pressure to a greater extent (15-35 per cent) under identical conditions. The hypotensive effect of kopsine (vary- ing the dosage between 2-5 mgm. per kgm. bodyweight) is much greater than that caused by strychnine of same dosage. When such a higher dosage of strychnine is used, respiration stops and there are marked convulsions and inhibition of cardiac contractions. But with higher dosage of kopsine convulsions never occurred in toads or cats.

Thus physiologically, kopsine possesses cholinergic effects, and its site of action is peripheral and not at the cerebrospinal axis as is that of strychnine. In the experimental preparations mentioned, it has also been found that kopsine and strychnine do not antagonize each other. Curiously enough, the hypotensive effect seen with kopsine has been observed in the deacetylated products of aspidospermine ${ }^{8}$, which is of the same origin (family: Apocyanacere) as is kopsine. Strychnos alkaloids are, however, of different origin (family: Loganiaceze).

Whether in the biogenesis of strychnos alkaloids the cholinergic action has been shifted from a peripheral effect (heart, smooth muscles, etc.) to $a$ central effect (central nervous system) is now boing investigated, as well as physiological properties $f$ acetylated and deacetylated products of strychnine and allied substances.

We thank Dr. A. Chatterji and A. Bhattacherjya, Department of Pure Chemistry, University College of Science, University of Calcutta, for the supply of the chromatographically enalysed drugs used for these experiments.

\section{S. R. MUkherJele AJIT MaItI P. K. DEY}

Department of Physiology,

University College of Science and Technology,

Department of Experimental Medical Sciences,

Medical College, Calcutta.

1 Bhattacharjya, A., Science and Culture, 18, 293 (1952).

'Bhattacharjya, A., Chatterji (née Mukherjee), A., and Bose, P. K., J. Amer. Chem. Soc., ry, 3370 (1949).

Bhattacharjya, A., Science and Cullure, 22, 120 (1956).

"Anet, F. A. L., and Robinson, R., J. Chem. Soe, 2253 (1955).

s Millson, M. F., Robinson, R., and Thomas, A. F., Experientia, 9, 89 (1953).

' Robinson, R., and Thomas, A. F., J. Chem. Soc., 3522 (1954)

${ }^{7}$ Karrer, P., Nature, 176, 277 (1955).

s Janot, M. M., Men, J. L., Aghoramurthy, K., and Robinson, R., Experientia, 11, 343 (1955).

\section{An Antibiotic from Maggots}

IN 1929, Baer ${ }^{1}$ introduced maggot therapy into clinical practice as an adjunct to surgery for the treatment of osteomyelitis. This technique became widely used in North America, and was extended to the treatment of other lesions where there was pyo. genic infection or tissue necrosis ${ }^{2}$. Maggots were believed to have a threefold action within a wound: débridement of necrotic tissue by means of proteolytic enzymes ${ }^{x}$, stimulation of granulation tissue due to the larval excretion allantoin ${ }^{3}$ and reduction of wound infection. Baer ${ }^{1}$ did not consider reduction of wound infection to be merely the result of débride. ment and tissue stimulation, and Robinson ${ }^{3}$ has shown that allantoin, even in concentrations up to 8 per cent, has no antibacterial activity.

The work described in the present communication has been undertaken because it was considered that an anti-bacterial agent, having the pronerties of a true 